\title{
PENGARUH SISTEM TEKNOLOGI INFORMASI PADA MANAJEMEN DATA DAN INFORMASI DALAM LAYANAN KEPERAWATAN: LITERATURE REVIEW
}

\author{
Indah Mulyani ${ }^{1}$, Elviawaty Muisa Zamzami ${ }^{2}$, Niskarto Zendrato ${ }^{3}$ \\ Fakultas Ilmu Keperawatan, Universitas Sumatera Utara ${ }^{1}$ \\ Fakultas Ilmu Komputer dan Teknologi Informasi, Universitas Sumatera Utara ${ }^{2,3}$ \\ Email : indahm1884@ gmail.com ${ }^{1}$
}

\begin{abstract}
ABSTRAK
Tujuan penulisan artikel ini adalah untuk mengidentifikasi pengaruh Sistem Teknologi Informasi pada Manajemen Data dan Proses Informasi dalam Layanan Keperawatan. Metode yang digunakan ialah dengan melakukan pencarian artikel melaui basis data elektronik: ProQuest, EmeraldInsight dan Google Scholar, menggunakan kata kunci Informasi Sistem,. Jumlah artikel yang ditinjau adalah sebanyak 15 artikel yang terkait. Hasil: dari kajian literatur yang dilakukan di dapatkan hasil bahwa Sistem teknologi informasi memberikan dampak yang efektif dan efesien dalam pelayanan keperawatan, perawat dapat meminimalkan waktu untuk melengkapi administrasi pasien, dan kegiatan inti lainnya dari manual menjadi komputerisasi. Sistem Informasi teknologi dalam keperawatan juga bertujuan untuk menjaga keamanan dan kerahasiaan data pasien, memberikan dan menerima informasi yang bermanfaat dan akurat bagi profesi lainnya. Dapat ditarik kesimpulan bahwa Sistem Manajemen Penggunaan informasi dalam ruang lingkup kesehatan dan khususnya pada bidang keperawatan telah memberikan dampak positif bagi pengembangan dan peningkatan sektor kesehatan juga telah memberikan kontribusi dalam meningkatkan kualitas layanan keperawatan bagi masyarakat.
\end{abstract}

Kata Kunci: Sistem; Informasi; Teknologi; Manajemen Data; Perawat

\begin{abstract}
The purpose of this literary study is to identify the influence of Information Technology Systems on Data Management and Information Processes in Nursing Services. The method used is to search articles through an electronic database: ProQuest, EmeraldInsight and Google Scholar, using the keywords Information System ,. The number of articles reviewed was 15 related articles. Results: From the literature review conducted it was found that the information technology system provides an effective and efficient impact in nursing services, nurses can minimize the time to complete patient administration, and other core activities from manual to computerized. Information Systems technology in nursing also aims to maintain the security and confidentiality of patient data, provide and receive useful and accurate information for other professions. It can be concluded that the Management System The use of information in the scope of health and especially in the field of nursing has had a positive impact on the development and improvement of the health sector has also succeeded in improving the quality of nursing services for the community.
\end{abstract}

Keywords: System; Information; Technology; Data Management; Nurse 


\section{PENDAHULUAN}

Manajemen informasi dalam keperawatan menjadi perhatian saat era Industri 4.0 sekarang ini. Sistem rumah sakit yang berbasis Teknologi Informasi dirasa memiliki banyak dampak positif dalam pelayanan kesehatan yang diberikan kepada masyarakat. Pada penerapannya, ada banyak kategori kegiatan keperawatatan yang dapat terintegrasi dengan sistem Informasi Teknologi Rumah Sakit, sebagai salah satu contohnya ialah pendokumentasian keperawatan. Sistem pendokumentasian keperawatan memberikan informasi tentang kegiatan pelayan keperawatan selama pasien dirawat di Rumah Sakit. Banyaknya beban kerja perawat menjadikan pencatatan dengan digital dianggap lebih memudahkan perkerjaan jika dibandingkan dengan pencatatan manual.

Sistem informasi adalah suatu metode yang menunjang kegiatan operasional dengan menyajikan informasi yang diperlukan oleh organisasi. Dalam prosesnya, terdiri dari tahapan input yang memghasilkan laporan, kemudian tahap penyimpanan yang berfungsi untuk mengelola, memelihara dan menyimpan data, kemudian tahap pengontrolan yang akan memberikan jaminan bahwa sistem informasi telah berfungsi sesuai dengan tujuan yang diharapkan. (Putri, A. Fadhilna, 2018).

$$
\text { Informatika dalam bidang }
$$

keperawatan dapat dikatakan masih relatif baru, untuk itu perlu ditetapkan instrumen spesisfik yang akan merangkum keperawatan sebagai sebuah profesi. Temuan penelitian Abdrbo, Amany A., 2010 menyebutkan bahwa melalui Information Systems Use Instrument (ISUI), diperkirakan dapat memberikan potensi untuk menentukan penggunaan sistem informasi pada praktik keperawatan. Instrumen yang baru dikembangkan ini adalah instrumen nonattitudinal pertama yang merupakan instrumen yang didasarkan pada proses keperawatan, spesifik keperawatan yang cukup singkat, mudah digunakan, dan dapat memberikan banyak informasi.

Semakin tingginya tuntutan penggunaan sistem informasi teknologi dalam berbagai bidang menjadi tantangan tersendiri bagi para pemberi layanan keperawatan dan kesehatan untuk mengintegrasikan setiap kegiatan yang diberikan kepada pasien atau klien dalam laporan dan pencatatan dokumen dalam bentuk digital atau komputerisasi, yang terangkum dalam sistem manajemen informasi teknologi.

\section{METODE}

Paper ini berdasarkan tinjauan sistematik dari beberapa artikel jurnal penelitian yang dipublikasi pada basis elektronik. Adapun basis data elektronik yang digunakan antara lain: ProQuest, EmeraldInsight dan Google Scholar dengan rentang waktu tahun 2010 sampai dengan tahun 2019.

Identifikasi jurnal terkait topik yang diangkat diindentifkasi melalui abstrak penelitian. Bila sesuai dengan topik terkait maka dapat dipertimbangkan untuk dijadikan referensi literature review. Hasil akhir dari seleksi jurnal atau artikel yang diperoleh dan dilakukan critical appraisal yaitu 5 jurnal.

\section{HASIL DAN PEMBAHASAN}

\subsection{Hasil}

Sistem Manajemen Informasi

Teknologi telah menjadi media yang efektif dalam kegiatan sehari-hari, termasuk dalam pemberian layanan kesehatan dan khususnya 
bagi layanan keperawatan, Dengan sistem infomasi teknologi memfasilitasi perawat untuk lebih meningkatkan efesiensi dan kualitas pelayanan pasien menjadi lebih baik dengan meminimalkan waktu untuk melengkapi administrasi pasien, dan kegiatan inti lainnya dari manual menjadi komputerisasi. Sistem Informasi teknologi dalam keperawatan juga bertujuan untuk menjaga keamanan dan kerahasiaan data pasien, memberikan dan menerima informasi yang bermanfaat bagi profesi lainnya yang terkait dalam layanan kesehatan pasien, dan juga dapat mendukung proses keperawatan.

\subsection{Pembahasan}

Keperawatan yang merupakan bagian dari layanan kesehatan yang dinamis dan terus berubah tentu melihat perkembangan dunia dan ilmu pengetahuan. Perkembangan dunia digital yang sangat pesat dan tuntutan kebutuhan masyarakat digital saat sekarang ini menjadikan keperawatan harus terus berubah dan beradaptasi dengan percepatan perkembangan dunia pelayanan kesehatan. Melihat efek penggunaan sistem informasi teknologi dalam proses pemberian pelayanan keperawatan mendapat cakupan yang cukup luas dan terus mengalami perkembangan.

Kegiatan sehari-hari keperawatan cukup beragam, terdiri atas tugas inti, pelayanan asuhan keperawatan kepada pasien yang terdiri dari perencanaan, pelaksanaan, dan dokumentasi asuhan keperawatan sesuai dengan proses perawatan, dan pelayanan administrasi keperawatan lainnya yang dapat berupa pendataan pasien, penggunaan obat-obatan, manajemen lingkungan, dokumentasi dan komunikasi dengan profesional lain. Sistem informasi keperawatan berbasis komputer yang digunakan oleh perawat menjadi dukungan yang positif dalam pekerjaan sehari-hari. Dalam pada penggunaan aplikasinya, sistem informasi keperawatan dapat berdiri sendiri atau lebih sering menjadi bagian dari rekam medis klinis elektronik (EMR) yang akan memungkinkan perawat memberi akses atau informasi klinis untuk dan dari profesi kesehatan lainnya.

Finkelman (2019) menyebutkan bahwa perawat dituntut untuk aktif dibidang informatika sebagai spesialisasi dan sebagai bagian dari tanggung jawab mereka yang lain. Seorang perawat dapat bertugas dikomite informatika atau berpartisipasi dalam perencanaan untuk implementasi rekam medis elektronik; jika perawat memiliki keahlian informatika tingkat lanjut, perawat dapat memimpin atau membantu perencanaan, implementasi, dan evaluasi informatika organisasi utama. Nursing Informatics Nursing Group mendefenisikan Informatika keperawatan/Nursing Information (NI) sebagai bidang khusus yang berkembang pesat dalam bidang sains dan praktik keperawatan yang terintegrasi informasi dan pengetahuannya dengan manajemen informasi dan teknologi komunikasi untuk mempromosikan kesehatan masyarakat, keluarga, dan komunitas di seluruh dunia"(American Medical Informatics Association, 2015).

Dari jurnal-jurnal yang dilakukan pengkajian di simpulkan bahwa percepatan perkembangan pelayanan kesehatan yang berbasis komputerisasi, menuntut perawat untuk terus bergerak dan menyesuaikan kemampuan, pengetahuan dalam bidang sistem informasi teknologi, yang pada akhirnya akan mampu memberikan efesiensi dan peningkatan kualitas layanan keperawatan, mampu menjaga keamanan dan kerahasiaan data pasien, dan sistem informasi 
teknologi juga memberikan dukungan pada proses keperawatan.

1. Meningkatkan efesiensi dan kualitas pelayanan pasien yang lebih baik

Dalam sebuah penilitian disebutkan bahwa untuk mengidentifikasi efek yang dirasakan dari masing-masing teknologi terhadap efisiensi alur kerja/ workflow efficiency (WFE) dan perawatan pasien yang berkualitas (QPC) dilakukan survei pada 462 responden tentang teknologi AORN. Hasil survei tersebut melaporkan bahwa merasakan dampak dari penggunaan teknologi (USE) di semua kategori. Dan 11 (Sebelas) dari 17 item RFID memiliki korelasi positif yang kuat antara item USE yang ditunjuk dengan efek yang dirasakan pada efesiensi alur kerja/ workflow efficiency (WFE) dan perawatan pasien yang berkualitas/ quality patient care QPC (Sipes Carolyne, 2015).

Dalam jurnal Information and Communication Technology in the Role of Information System of Healthcare Facility in the Slovak Republic, dijelaskan bahwa $E$ Health Memberikan kesempatan untuk mendapatkan data dari Pasien, fasilitas medis, dan rumah sakit untuk satu tempat di tim yang sama. Ini Memastikan kualitas dan keamanan pelayanan, kelangsungan layanan, dan biaya talangan. Seperti diketahui di berbagai negara, e-health adalah salah satu cara untuk membuat pekerjaan lebih mudah dan lebih efektif. (Gavurová Beáta, 2019)

Dan pada hasil penelitian lainnya menyebutkan bahwa keperawatan yang berbasis Sistem Informasi komputer telah dapat memberikan efek beragam dalam pelayanan keperawatan, dan juga telah ditemukan dengan jelas peningkatan kualitas proses informasi, serta persepsi perawat berkaitan dengan penghematan atau kerugian waktu yang dapat di minimalkan dalam proses pelayanan keperawatan. (Ammenwertha Elske,et.al, 2010). Setiap kegiatan perawat yang sebelumnya dilakukan secara manual, dengan adanya sistem informasi teknologi dapat memberikan efesiensi waktu dan juga efektifitas pekerjaan.

Sejalan dengan penelitian lainnya, Fang Ho Kuei (2019) juga menyebutkan bahwa perawat mengelola catatan kesehatan dan perawatan klinis elektronik dalam praktik rutinnya, penggunaan catatan kesehatan telah meningkat hingga $80 \%$. Sistem Informasi keperawatan (NIS) terdiri dari modul terintegrasi tentang catatan kesehatan elektronik, yang dapat memberikan bantuan teknologi untuk mengelola semua ketegori tugas perawat dan mampu meningkatkan efesiensi alur kerja.

2. Menjaga keamanan dan kerahasiaan data pasien

Keamanan dan kerahasiaan data pasien merupakan hal yang penting diperhatikan untuk menjaga kepercayaan pasien pada pemberi layanan kesehatan. Untuk itu, Electronic Health Record (EHR) menjadi sumber daya informasi pada perawatan pasien untuk dokter dan dokumentasi keperawatan yang merupakan bagian penting dari perawatan pasien secara komprehensif. Memastikan privasi dan keamanan informasi kesehatan adalah komponen kunci untuk membangun kepercayaan yang dibutuhkan untuk mewujudkan potensi manfaat pertukaran informasi kesehatan elektronik. Untuk itulah Penelitian oleh Samadbeik, Mahnaz (2015) bertujuan mengelola keamanan data keperawatan pasien melalui Electronic Health Record (EHR) dan juga menemukan 
sudut pandang vendor rumah sakit terhadap sistem informasi teknologi.

3. Memberikan informasi yang bermanfaat dan akurat

Procter Paula and Ian Woodburn

(2012) dalam penelitiannya menyebutkan bahwa perawat merupakan profesi yang sangat dekat dengan pasien karena terus menerus memberi pelayanan selama 24 jam sehari. Sehingga mereka menjadi dasar utama, arus masuknya informasi pasien ke dalam sistem manajemen informasi dalam perawatan kesehatan. Namun, peran ini akan menjadi sukses jika perawat memiliki pengetahun tentang sistem informasi teknologi yang baik, memiliki pengetahuan tentang manajemen, keterampiran kepemimpinan dan output informasi yang relevan dengan kondisi pasien. Maka, semakin baik pengetahuan perawat tentang pentingnya sistem informasi teknologi maka semakin baik pula informasi kesehatan dalam rekam jejak perawatan kesehatan pasien. Untuk itu, menjadi penting seorang perawat paham dan mampu menjalankan aplikasi teknologi informasi dalam setiap kategori kegiatan yang menjadi tugas dan tanggung jawabnya.

Australian residential aged care (RAC) atau Rumah perawatan lansia Australia yang menggunakan electronic health records (EHR) telah memenuhi semua standar akreditasi secara signifikan dengan kategori yang lebih tinggi jika dibandingkan dengan rumah perawatan lansia yang menggunakan catatan kertas. (Jiang Tao, et.al, 2016) dari penelitian tersebut diketahui bahwa pencatatan dengan menggunakan sistem informasi teknologi mampu memberikan akses informasi yang akurat dan tepat, meminimalkan kegagalan dalam mekanisme pemantauan, mengefektifkan pelaporan insiden klinis, dan mampu mengurangi risiko kesalahan komunikasi dan informasi yang terjadi.

\section{Mendukung Proses Keperawatan}

Sebagai bagian dari sistem pelayanan kesehatan, keperawatan memiliki proses pemberian Asuhan Keperawatan yang dimulai dari tahap perencanaan, diagnosa keperawatan, intervensi, implementasi dan evaluasi yang setiap tahapan prosesnya memerlukan pencatatan dan pendokumentasian sebagai bukti tindakan pelayanan yang diberikan. Dan dengan sistem informasi teknologi pencatatan dokumentasi keperawatan dapat dilakukan dalam bentuk digital atau komputerisasi, seperti yang telah didefenisikan oleh The American Nurses Association (ANA) bahwa Nursing Informatics (NI): merupakan Keperawatan Informatika dengan spesialisasi keperawatan yang terintegrasi dengan ilmu pengetahuan, ilmu komputer, dan informasi pengetahuan yang mengidentifikasi, mengumpulkan, mengolah, dan mengelola data juga informasi yang mendukung praktik keperawatan, administrasi pendidikan, penelitian, dan perluasan pengetahuan keperawatan. ANA juga mendukung penerapan standar penggunaan bahasa keperawatan (Murphy Judy, 2010). Proses pendokumentasian keperawatan yang merupakan pelaporan dari kegiatan-kegiatan yang dilakukan oleh perawat, memerlukan input data yang detail dan teliti, untuk itu sistem informasi teknologi yang menjadi alat dalam pencatatan pendokumetasian keperawatan, diharapkan mampu meningkatkan keakuratan data yang dilaporkan. 


\section{KESIMPULAN DAN SARAN}

\subsection{Kesimpulan}

Penggunaan Sistem Manajemen informasi teknologi dibidang kesehatan dan khususnya pada bidang keperawatan telah memberikan dampak yang positif tehadap perkambangan dan kemajuan bidang pelayanan kesehatan juga telah dirasakan efek yang baik oleh penerima layanan yaitu masayarakat maupun pemberi layanan keperawatan. Pada akhirnya penggunaan Sistem Informasi teknologi dalam bidang keperawatan diharapkan mampu memberikan kontribusi yang mampu meningkatkan efektifitas, efesiensi, dan kualititas pelayanan serta menjaga keamanan dan keselamatan pasien selama dalam masa perawatan.

\subsection{Saran}

Sangat cepat dan pesatnya pertumbuhan sistem infomasi teknologi disaat sekarang ini, menjadikan profesi keperawatan harus terus mampu bersinergi dengan perubahan-perubahan tersebut, agar mampu menciptakan pelayanan keperawatan yang bermutu berkualitas dan sesuai dengan perkembangan dunia kesehatan.

\section{DAFTAR PUSTAKA}

Abdrbo, Amany A., RN, BSN, PhD. 2010. Development and Testing of Nurses Information Systems Use Instrument Journal of Nursing Measurement Volume 18

Ammenwerth, Elske., Et.al. 2010. Effect of a nursing information system on the quality of information processing in nursing: An evaluation study using the HIS-monitor instrument. International journal of medical informatics
Black, Beth Perry., PhD, RN. 2017. Professional Nursing Concepts \& Challenges. Elsevier. St. Louis, Missouri

Fang,Ho Kuei., et.al. 2019. Theoretical integration of user satisfaction and technology acceptance of the nursing process information system. PlOs-One

Gavurová, Beáta., Ballon Antonio José i., et.al. 2018. Information and Communication Technology in the Role of Information System of Healthcare Facility in the Slovak Republic. Journal economies

Jiang, Tao, et.al,. 2016. The Impact of Electronic Health Records $n$ Risk Management of Information Systems in Australian Residential Aged Care Homes. DOI 10.1007/s10916-0160553-y

Murphy, Judy., 2010. Nursing Informatics: The Intersection of Nursing, Computer, And Information Sciences, Journal of Nursing Economic\$/May-June 2010/Vol. 28/No. 3

Procter, Paula., Woodburn., Ian. 2015 Encouraging nurses to develop effective electronic documentation. Journal of Nursing Mangement

Samadbeik., Mahnaz. 2015. Managing the Security of Nursing Data in the Electronic Health Record. Acta Inform Med. 2015 Feb 23(1): 39-43 / Original Paper 